\title{
Analisis Jangkauan Dan Baud Rate Transmisi Data Pada Sistem Telemetri Temperatur Berbasis Mikrokontroler
}

\author{
Nurjannah $^{{ }^{*}}$, Lilik Hasanah ${ }^{1}$, Ahmad Aminudin ${ }^{1}$ \\ ${ }^{1}$ Departemen Pendidikan Fisika, Fakultas Pendidikan Matematika dan Ilmu \\ Pengetahuan Alam, Universitas Pendidikan Indonesia, Jl. Dr. Setiabudhi No 229 \\ Bandung 40154, Indonesia \\ * Penulis Penanggungjawab.E-mail : nur.jannah.a2f@gmail.com \\ Telp/hp : 082316700295
}

\begin{abstract}
ABSTRAK
Pengujian jangkauan dan boud rate transmisi data pada sistem telemetri temperatur dilakukan untuk menganalisis pengaruhnya terhadap data yang ditransmisikan. Alat-alat yang digunakan untuk menganalisisnya adalah sensor temperatur LM35, perangkat transmitter, perangkat receiver dan PC. Adapun metode yang dilakukan untuk pengujian jangkauan transmisi data adalah dengan cara mentransmisikan data pada jangkauan 1 meter sampai dengan 10 meter. Sedangkan untuk melakukan pengujian pengaruh boud rate terhadap data yang ditransmisikan dilakukan dengan cara memvariasikan boud rate perangkat receiver pada setiap transmisi data.

Kata Kunci : jangkauan ; boud rate ; perangkat transmitter; perangkat receiver.
\end{abstract}

\begin{abstract}
Testing of the extent and baud rate of data transmission on temperature telemetry system was conducted to analyze its effect to the transmitted data. The tools that was used to analyze it was LM35 temperature sensor, transmitter devices, receiver devices and PC. The method that was carried out to test the extent of the data transmission was by transmiting data on a range of 1 meter to 10 meters. As for
\end{abstract}


testing the effect of baud rate against data that was transmitted was done by varying the baud rate on receiver device at any transmission of data.

Keywords $\quad$ : extent; baud rate; transmitter device; reciever device.

\section{Pendahuluan}

Seiring perkembangan teknologi sistem pengukuran suatu besaran dapat diukur dengan jangkauan yang cukup jauh, hal ini lebih dikenal dengan istilah sistem telemetri. Menurut Kodong [1] telemetri merupakan sistem pengukuran dari suatu objek terukur dengan menempatkan penyajian data hasil ukur pada tempat yang terpisah. Oleh sebab itu karena penyajian data yang terpisah tersebut, maka sistem telemetri memanfaatkan jaringan tanpa kabel (nirkabel). Data hasil pengukuran yang dapat dikirim menggunakan sistem telemetri di antaranya adalah data hasil pengukuran temperatur.

Temperatur merupakan suatu besaran fisika yang didefinsikan sebagai ukuran panas atau dinginnya suatu benda. Ukuran panas atau dinginnya suatu benda hanya dapat dirasakan dan tidak dapat diukur secara langsung. Untuk itu diperlukan suatu alat yang dapat mendeteksi perubahan temperatur yang ada dilingkungan seperti sensor temperatur LM35. Sensor temperatur LM35 mendeteksi perubahan temperatur disekitarnya dan merubahnya ke dalam besaran fisika berupa tegangan keluaran.

Tenganan keluaran yang diperoleh dari sensor akan dikonversikan kedalam bentuk hasil pengukuran secara kuantitaf dengan satuan derjat celcius

$\left({ }^{\circ} \mathrm{C}\right)$ menggunakan mikrokontroler arduino uno. Hasil pengukuran tersebut dikirim menggunakan modul wireless xbee. Semua perangkan ini disebut sebagai perangkat transmitter.

Data yang dikirim tersebut akan diterima oleh perangkat receiver yang terdiri dari xbee receiver dan PC sebagai display.

Sebelumnya telah terdapat beberapa penelitian yang berkaitan dengan sistem telemetri temperatur, di antaranya Kodong [1] melakukan 
penelitian berkaitan dengan telemetri suhu yang di aplikasikan sebagai penentu status gunung berapi. Penelitian lainnya juga dilakukan oleh Novianta [2] yang membahas tentang telemetri temperatur dengan program visual basic. Oleh sebab itu berdasarkan beberapa penelitian tersebut maka pada penelitian ini dibahas tentang telemetri telemperatur, namun lebih menitik beratkan pada analisis beberapa faktor yang dapat mempengaruhi transmisi data hasil pengukuran, diantaranya adalah analisis jangkauan dan baud rate transmisi data.

\section{Landasan Teori}

\section{Jangkauan Transmisi Data}

Pada sistem telemetri temperatur, jangkauan merupakan salah satu faktor yang dapat mempengaruhi hasil pengiriman data dari perangkat transmitter ke perangkat receiver. Hal ini disebabkan karena jangkauan pengiriman data tersebut sangat erat hubungannya dengan daya pancar/ intensitas . Semakin besar jangkauan transmisi data, maka daya pancar yang sampai pada jangkauan tersebut akan semakin berkurang. Hal ini bersesuaian dengan hukum square dimana suatu intensitas berbanding terbalik terhadap kuadrat jarak. Berikut ini persamaan hukum square

$$
I=\frac{P}{4 \pi r^{2}} \ldots \cdots \cdots
$$

\section{Baud Rate}

Agar data yang dikirim oleh perangkat transmitter ke perangkat receiver dapat tersingkronisasi dengan baik, maka perlu diperhatikan boud rate saat transmisi data tersebut. Menurut Tittle [3] boud rate adalah jumlah pulsa yang dikirimkan dalam setiap detik, melalui saluran transmisi tertentu. Sebagai contoh dalam mentransmisikan data digunakan baud rate 9600, yang artinya dalam setiap detik dapat ditransmisikan 9600 boud (karakter). Satuan baud rate adalah bps (baud per secon). Terdapat beberapa besaran baud rate di antaranya adalah 1200, 2400, 4800, 9600, 19200, 38400, 57600, dan 115600 .

\section{Sensor Temperatur LM 35}


Menurut Novianta [2] sensor tegangan pada skala Celsius adalah temperatur LM35 merupakan $\quad 10 \mathrm{mV} /{ }^{\circ} \mathrm{C}$ dengan akurasi $\pm 1 / 4^{\circ} \mathrm{C}$ pada komponen elektronis berupa IC yang suhu ruang, dengan rentang suhu mampu menghasilkan tegangan yang dapat direspon antara -55sebanding dengan besaran suhu yang $150^{\circ} \mathrm{C}$.

menyelimuti. Linieritas keluaran

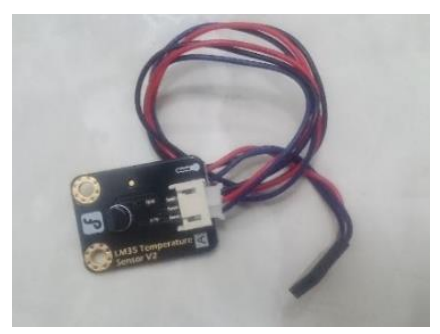

Gambar 1. Modul Sensor LM35 DZ

\section{Mikrokontroler}

Artanto [4] menyatakan bahwa “... mikrokontroler adalah sebuah alat pengendali (kontroler) berukuran mikro atau sangat kecil yang dikemas dalam bentuk chip". Dalam penelitian ini mikrokontroler yang digunakan adalah arduino uno .Menurut Boando dan Winardi [5] arduino uno adalah sebuah board mikrokontroler berbasis Atmega328.

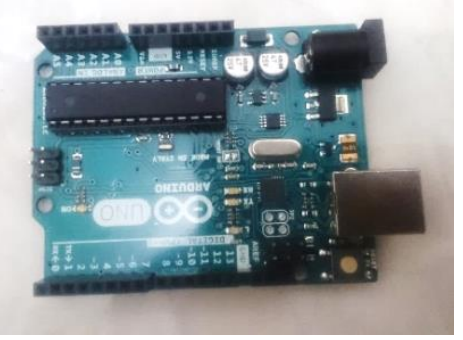

Gambar 2. Arduino Uno

\section{Xbee Series 1}

Menurut Raju [6] xbee merupakan modul komunikasi wireless yang memenuhi standar IEEE 802.15.4.
Xbee dapat beoperasi dengan daya yang rendah, jarak jangauan yang pendek dan dapat diaplikasikan untuk pengiriman data secara real 
time. Selain itu xbee beroperasi pada frekuensi 2,4 GHz.

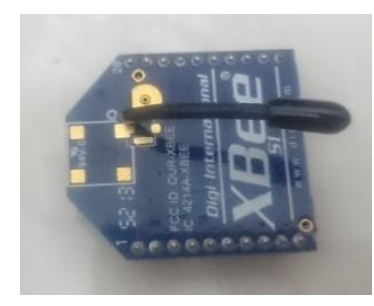

Gambar 3. xbee series 1

\section{Metoda}

Pengujian jangkauan dan boud rate pada sistem telemetri temperatur dilakukan dengan metoda berikut ini. Pada tahap awal rangkai alat-alat seperti pada skema dibawah ini:

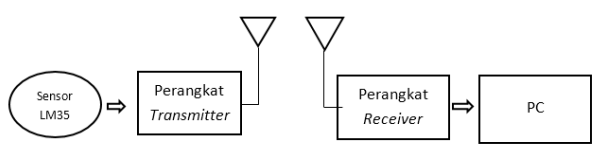

Gambar 4. Skema rangkaian alat pengujian jangkauan dan baud rate pada sistem telemetri temperatur.

Untuk tahap pengujian jangkauan dilakukan dengan cara memvariasikan jangkauan antara perangkat transmitter dengan perangkat receiver dari jangkauan 1 meter sampai 10 meter. Pada setiap jangkauan tersebut dilihat pengaruhnya terhadap hasil transmisi data yang diterima oleh perangkat receiver.
Sedangkan untuk pengujian boud rate dilakukan dengan cara memvariasikan boud rate pada perangkat receiver. Pada setiap variasi boud rate dari perangkat receiver dilihat pengaruhnya terhadap hasil transmisi data yang diterima oleh perangkat receiver.

\section{Hasil Dan Analisis}

Setelah dilakukan penelitian maka diperoleh data pengaruh jangkauan terhadap kevalidan hasil transmisi data pengukuran pada tabel 1 berikut ini : 
Tabel 1. Pengaruh jangkauan terhadap kevalidan hasil transmisi data

\begin{tabular}{ccc}
\hline NO & $\begin{array}{c}\text { Jangkauan } \\
\text { (meter) }\end{array}$ & $\begin{array}{c}\text { Kevalidan Hasil } \\
\text { Transmisi Data } \\
(\%)\end{array}$ \\
\hline 1. & 1 & 100 \\
\hline 2. & 2 & 100 \\
\hline 3. & 3 & 100 \\
\hline 4. & 4 & 100 \\
\hline 5. & 5 & 100 \\
\hline 6. & 6 & 100 \\
\hline 7. & 7 & 100 \\
\hline 8. & 8 & 100 \\
\hline 9. & 9 & 100 \\
\hline 10. & 10 & 75 \\
\hline
\end{tabular}

Sedangan pengaruh boud rate data dapat dilihat pada tabel 2 berikut terhadap kevalidan hasil transmisi ini :

Tabel 2. Pengaruh boud rate terhadap kevalidan hasil transmisi data

\begin{tabular}{cccc}
\hline No & $\begin{array}{c}\text { Boud Rate } \\
\text { Transmitter }\end{array}$ & $\begin{array}{c}\text { Boud Rate } \\
\text { Receiver }\end{array}$ & $\begin{array}{c}\text { Valid Data } \\
(\%)\end{array}$ \\
\hline 1 & 9600 & 4800 & 75 \\
\hline 2 & 9600 & 9600 & 100 \\
\hline 3 & 9600 & 19200 & 100 \\
\hline 4 & 9600 & 38400 & 100 \\
\hline
\end{tabular}

Berdasarkan tabel 1. pengaruh jangkauan terhadap kevalidan hasil transmisi data dapat dianalisis bahwa semakin besar jangkauan pengiriman data, maka kevalidan data semakin berkurang. Hal ini terjadi karena daya pancar/intensitas yang mencapai jangkauan tersebut akan semakin berkurang, hal ini bersesuaian dengan hukum square tentang hubunga intensitas yang berbanding terbalik dengan kuadrat jarak.

Untuk pengaruh boud rate terhadap hasil transmisi data berdasarkan tabel

2. dapat dianalisis bahwa saat baud 
rate receiver lebih kecil dari pada boud rate transmitter $(4800<9600)$, maka kevalidan hasil transmisi data akan berkurang. Hal ini disebabkan karena perangkat receiver sulit untuk mengsingkronkan hasil transmisi data dengan data yang di kirim oleh perangkat transmitter. Namun berbeda halnya jika baud rate receiver lebih besar sama dengan boud rate transmitter $\quad(9600 \geq$ 9600; 19200; 38400), maka hasil transmisi data yang diperoleh akan lebih valid. Hal ini disebabkan karena perangkat receiver dapat mengsingkronkan hasil transmisi data dengan baik pada data yang di kirim oleh perangkat transmitter.

\section{Simpulan}

Berdasarkan penelitian yang telah dilakukan dapat disimpulkan bahwa jangkauan pengiriman data berpengaruh terhadap hasil transmisi data. Semakin besar jangkauannya maka daya pancar/intensitas yang diterimanya akan semakin berkurang, sehingga hasil transmisi data akan berkurang kevalidannya.

Selain itu boud rate juga berpengaruh terhadap hasil transmisi data oleh perangkat transmitter terhadap perangkat receiver, hal ini berkaitan dengan singkronisasi data hasil transmisi. Untuk keaman tranmisi data boud rate perangkat receiver sebaiknya besar sama dengan boud rate perangkat transmitter.

\section{Referensi}

[1] Kodong, F.R. (2009). Aplikasi Penentu Status Gunung Berapi Menggunakan Telemetri Suhu. Seminar Nasional Informatika 2009.hlm E-57 - E-64.

[2] Novianta, M.A. (2010). Telemetri Suhu Secara Realtime Berbasis AskFm dengan Pemprograman Visual Basic.hlm D-1 - D6.

[3] Tittle, E. (2004). Teori dan Soal Computer Networking (Jaringan Komputer). Jakarta : Erlangga.

[4] Artanto, D. (2009). Merakit PLC dengan Mikrokontroler. Jakarta :PT Elex Media Komputindo.

[5] Buando, T.H., inardi, S. (2016). Rancang Bangun Prototipe Sistem Pelacak Matahari Menggunakan 
Arduino. Jurusan Sistem Komputer

Fakultas Ilmu Komputer, Universitas

Narotama.

[6] Raju, P.V., Aravind, R.V.R.S.,

Kumar. B.S.(2013).Pollution

Monitoring System using Wireless

Sensor Network in Visakhapatnam.

International Journal of Engineering

Trends and Technology (IJETT). 4

(4).hlm.591-595. 